\title{
Regional Characteristics of the Belief in the Kanamura Betsurai Shrine between the Inner and Outer Areas
}

\author{
Keisuke MATSUI \\ Institute of Geoscience, University of Tsukuba, Tennodai, Tsukuba, 305-8571, Japan
}

\begin{abstract}
In this paper, I have tried to clarify the regional differences in the mode of people's belief in the Kanamura Shrine between the outer and inner areas of its religious sphere. In the Toyosato district, a typical district of the inner area, Kanamura religious associations $(k o)$ do not function as autonomous religious groups and are dependent upon other religious or administrative organizations, while the majority of the individual believers used to pray for the safety of soldiers before the war, and now pray for the safety of their own families. People in this area worshipped the Kanamura shrine not only as an efficacious deity but the tutelary status of the shrine. One of the factors causing people to regard the Kanamura Shrine as their tutelary deity is the close connection between the local communities and the shrine through the distribution of amulets and ceremonies in addition to people's visits to the shrine. In the Yoshikawa district, a typical district of the outer area, there are few individual believers but the Kanamura associations in this district have their own managers and members, and function independently of the ujiko, or other religious organizations. It is cleared that people in this area worshipped the Kanamura Shrine not as the tutelary deity but as a removed efficacious deity.
\end{abstract}

Key words: religious sphere, Kanamura Betsurai Shrine, Kanamura association, tutelary deity, efficacious deity

\section{Introduction}

Geographers of religion should strive to understand the religious structure of space thoroughly by adopting both positivistic and symbolic approaches (Matsui 1998). To analyze a religion in terms of geography, it is necessary to examine not only the distribution of its believers, but also the spatial structure created by their behavior and the religious landscapes delineated through their activities. The mode of a religious space varies according to the nature of the religion that has created that space. Therefore, a geographer of religion should not see religious space as homogenous. Instead, he/ she should clarify the geographical structure of the sacred and profane through comparing religious landscapes and distributional patterns of believers (Iwahana 1983a).

In the United States, there have been several attempts to clarify regional divisions on the basis of the distributional patterns of believers belonging to various Christian denominations, such as that of Zelinsky (1961), who divides the country into seven religious areas. While Zelinsky focuses on the dominant Christian denomination in each county in his classification, Shortridge (1976) examines spatial variations in three diagnostic aspects: the relative proportions of liberal and conservative Protestantism, the degree of religious diversity, and the level of religious intensity. In contrast to these generalized divisions, the study of Meinig (1965) concentrates on the Mormon culture region. Meinig divides it into three areas of core, domain, and sphere, and points out that these areas are distributed in a concentric pattern around Salt Lake City. Besides this study of Meinig on the Mormon culture region, there have been several studies on various culture regions growing out of particular religions, including the Texas culture region with German religious characteristics (Zelinsky 1973; Jordan 1976, 1980), the ethnic island of Dutch Reformed immigrants in Michigan (Bjorklund 1964), the cultural landscapes of Louisiana reflecting Roman Catholicism (Clarke 1985; Trepanier 1986), and the Amish and Mennonite ethnic areas in the East Coast (Hostetler 1980). 
Thus, in the United States, a religious tradition has a close connection with a particular ethnic or social group and, therefore, we can recognize regional differences in terms of religion. People in Japan, on the contrary, accept many different religions and these religions usually do not conflict with each other. Therefore, it is difficult to discern religious culture regions through church attendance or the density of believers.

Studies on religious spheres in Japan have mainly concerned mountain religions. Since time immemorial, Japanese people have worshipped mountains as the abode of kami (gods) or as a place for ascetic practices. Scholars have studied the spheres of these mountain religions from the viewpoint of spatial recognition (Ishitobi 1976; Ariga 1972; Iwahana 1981, 1983b). Since Miyata's attempt (1961) to identify concentric zones around the mountain worshipped, there have accumulated in the field of folklore several studies on the religious spheres of mountains including Mt. Iwaki (Miyata 1970), Mt. Kaba (Miyamoto 1974), and Mt. Tsukuba (Nishikai 1979; Maki 1980). Geographers have studied Mt. Hiko (Nagano 1987), the Three Mountains of Dewa (Iwahana 1983a), Mt. Togakushi (Iwahana 1992), and Mt. Furumine (Hashimoto 1987). As Kaneko (1995) points out, folklorists have recently begun to make a spatial model of the sphere of religion under the influence of Iwahana's works. We can see this trend in the studies on Mt. Oyama (Suzuki 1992) and Mt. Iwaki (Koyama 1995; Kaneko 1997).

This paper examines the religious sphere of the Kanamura Betsurai Shrine in Tsukuba, Ibaraki. The shrine has its believers among people in the agricultural areas extending from the southwestern part of Ibaraki to southeastern Saitama and northwestern Chiba. The purpose of this paper is to clarify regional differences in people's belief in the Kanamura Shrine between the inner and outer areas and utilizes as main data the list of the religious associations of the shrine (1985) and the visitor's book (1995) kept at the shrine office.

It is said that the Kanamura Shrine was built in 931 by Toyoda Masamoto, the first lord of the Toyodas, who transferred the sacred spirit from the Kamo Shrine in Kyoto. The Kanamura Shrine is located on the flood plain formed by the Kokai River, about 14 meters above sea level. The Kokai River had no fixed river channel until recently, and it often flooded its alluvial plain and caused severe damage after a heavy rain. Today, a crescent marsh exists along the river as a sign of repeated floods. However, legend has it that, the precinct of the Kanamura Shrine was never inundated even in the worst flood (Kushida 1978).

People living in the locality of the Kanamura Shrine have worshipped its agricultural deity since the time of its foundation, calling him Kanamura-sama or Rai-sama. As one of the three thunder shrines in the Kanto Region, the shrine extends its sphere beyond the area of its ujiko and throughout the region. Ujiko is a kind of Japanese religious system of shrines. People automatically become a member of the religious group performing at the festivals of one or a couple of shrines in their areas.

The ujiko region of the Kanamura Shrine consists of four old villages. Those are Kamigo, Tegomaru, Konomata and Nobata. These four old villages are divided into 29 districts. Between one and three persons are selected as managers in each district. Vicarious visitors are selected to dedicate new rice or to pray for gratitude in the fall festival. The main district of ujiko region is Raijin. It had been a shrine town before the 1960s. Two shrine maidens dance in three festivals. It is called an infant dancing. Both of the shrine maidens are selected in Raijin district. This district was situated beside the bank of the Kokai River. It was obliged to move outside the bank by a river improvement. The economic connection between the Kanamura Shrine and people in Raijin district disappeared at that point. People in this district have been in charge of the preparation of festivals.

Reflecting the vast sphere of the Kanamura Shrine, people's expectation of its efficacy has many aspects, ranging from the safety of one's family or one's health and longevity, to protection against hail and thunderstorms or having bumper crops (Toyosato-cho Shi Hensan Iinkai 1985). Because of its long history and wide extent of influence, the Kanamura Shrine 
makes a suitable object of a case-study for the purpose of clarifying regional characteristics of a sphere of religion.

\section{Distributional Pattern of the Believers of the Kanamura Shrine}

\section{Distribution of the Kanamura associations}

Figure 1 shows the distribution of the religious associations $(k o)$ of the Kanamura Shrine in $1985 .{ }^{1}$ These associations exist in 320 settlements in Ibaraki, Chiba, Saitama, and Tokyo.
Ibaraki has the most associations of 221 , which amounts to $69 \%$ of the total, followed by Chiba with 58 associations (18\%), and Saitama with 38 associations (11.9\%). As a city, town, or village, both Noda City in Chiba and Yatabe Town (currently Tsukuba City) in Ibaraki have the most associations of 26, followed by Mitsukaido City and Yawahara Village in Ibaraki with 24 and 20 associations respectively.

Though the origin of Kanamura association is not clear, it is supposed to be organized around the latter Edo or the Meiji era. The Kanamura association is organized in a rural

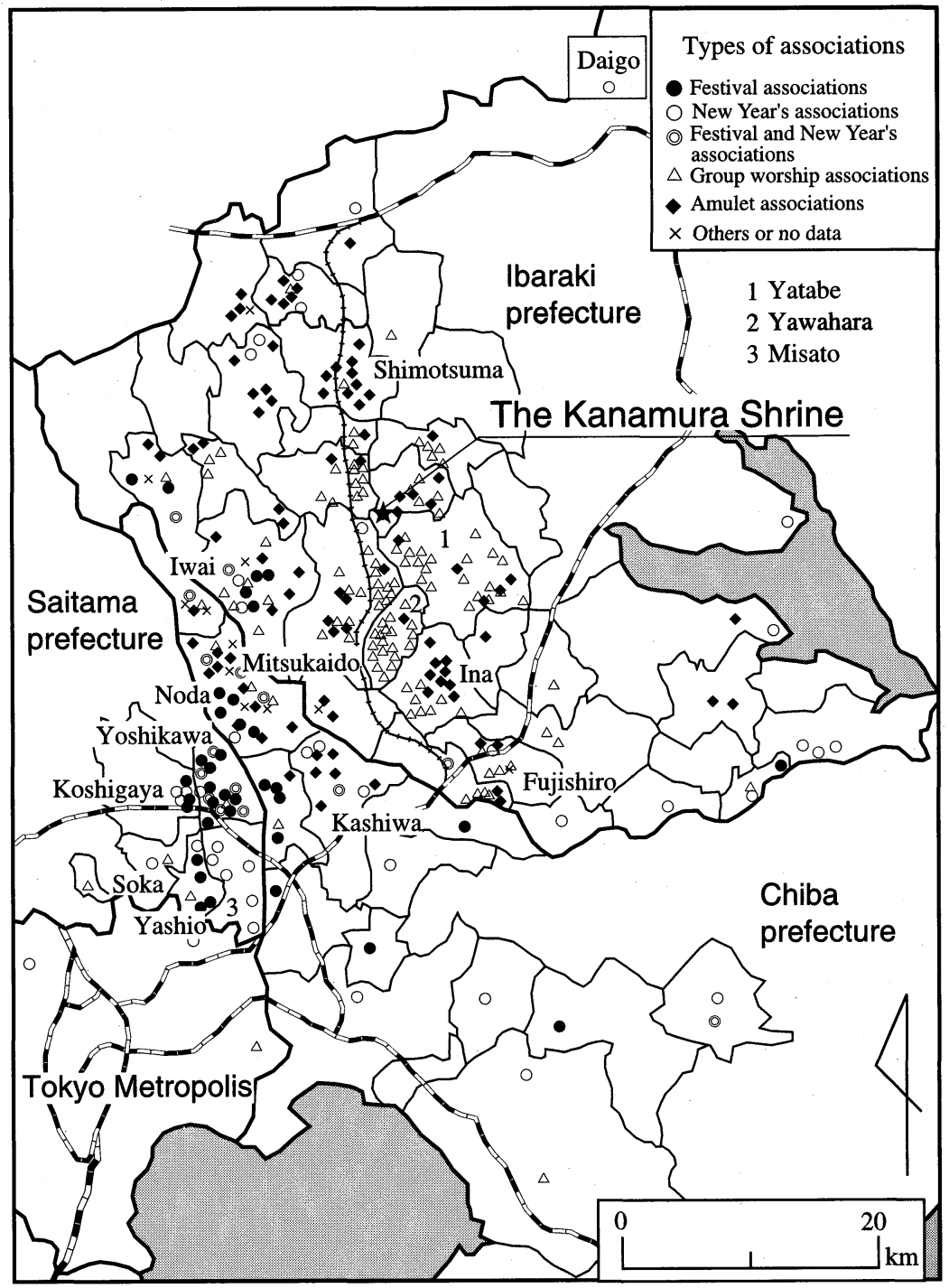

Figure 1. Distribution of Kanamura associations, 1985. Data source: The Kanamura Shrine office. 
community. There are four types, as follows.

1) The festival associations (daidai-ko) offer sacred dances (daidai-kagura) at the spring and fall festivals of the Kanamura Shrine. Although these associations used to visit the shrine at both of the two festivals, more and more of them make a visit only once a year these days. They, too, send their representatives to the shrine, to receive a large wooden amulet for the whole association, middle-sized amulets for the individual members, and amulets for protection against insects or disasters. Of all the Kanamura religious associations, this is the oldest type with many associations going back to the late Tokugawa to early Meiji period.

2) The New Year's associations (kinen-ko) make prayers at New Year. The members of these associations receive their amulets through mail. Some associations transformed themselves from festival associations to this type as their collective desire to visit the shrine declined due to the decreasing rate of farmers among their members.

3) The amulet associations (nichigetsunenzan-ko) visit the Kanamura Shrine daily, monthly, or yearly to get some amulets. There are no longer associations making daily visits to the shrine. The associations of monthly visits (tsukimairi-ko) send their representatives to the shrine every month through March to September. Nowadays, however, it is getting more common to send them only in March and September. The associations of yearly visits (nen$z a n-k o$ ) occupy $95 \%$ of the amulet associations and they send their representatives once a year, usually in spring or fall, that is, in March, April, September, or October. The representatives receive various types of amulets depending on the associations they represent, including boxed amulets or large wooden amulets for the well-being of one's community and amulets for protection against insects or disasters.

4) The group worship associations (dantaiko) visit the Kanamura Shrine once a year, either in April or November in the most cases. Some associations were organized before the Meiji period, and the members of these associations all visit the Kanamura Shrine together (so-mairi). In contrast, many of the associations were founded around the Second World War through the missionary efforts of the shrine and have the system of vicarious visit (daisan).

As for types of the associations, there are 124 (35.8\%) group worship associations, 104 (30\%) amulet associations, 63 (18.2\%) New Year's associations, and 54 (15.6\%) festival associations. $^{2}$ Of the 124 group worship associations, more than $90 \%$ exist in Ibaraki. They have their core area in the lower basin of the Kokai River centering upon Yawahara Village, Ina Town, Fujishiro Town, or in Yatabe Town and Mitsukaido City, the area adjacent to the Kanamura Shrine.

The core area of the festival associations and New Year's associations extends from southeastern Saitama to northern Chiba. More than $90 \%$ of the associations in Saitama belong to either one of these two types and are located especially in Yoshikawa Town (currently Yoshikawa City), Koshigaya City, Yashio City, and Misato City in the lower basin of the Naka River. In Chiba and Ibaraki, the proportion of these types to others is also high in the areas more than 30 kilometers away from the Kanamura Shrine.

The core area of the amulet associations lies within 20 kilometers from the shrine. None of these associations can be seen in Saitama, while many exist in Toyosato Town (currently Tsukuba City), Shimotsuma City, Mitsukaido City, Iwai City, and Yatabe Town in Ibaraki, and Noda City and Kashiwa City in Chiba. The distribution of the amulet associations reflects the fact that these associations originated in religious groups making prayers for rain. Before the Second World War, when irrigation systems were still underdeveloped, it was difficult to obtain enough water to grow crops in the villages on the dilluvial upland. These villages sent their representatives to the Kanamura Shrine and had the priests pray for rain. Then, the representatives brought back holy water with them and all the villagers gathered together to pray for rain. At the time, people had to walk or ride bicycles to the shrine and, as a result, the amulet associations nowadays are still confined to the area within a half-day walk from the Kanamura Shrine. 


\section{Distribution of individual believers of the Ka- namura Shrine}

Figure 2 shows the distribution of the people who asked for prayers at the Kanamura Shrine between April 1, 1995 and March 31, 1996, and also the time of the year they visited the shrine (hereafter we call them individual believers). ${ }^{3}$ These individual believers total $1031^{4}$ and spread over Tokyo and seven prefectures, that is, Ibaraki, Chiba, Saitama, Tochigi, Kanagawa, Aichi, and Nagano. Among them, 878 (85.2\%) live in Ibaraki. The Toyosato district in Tsu-
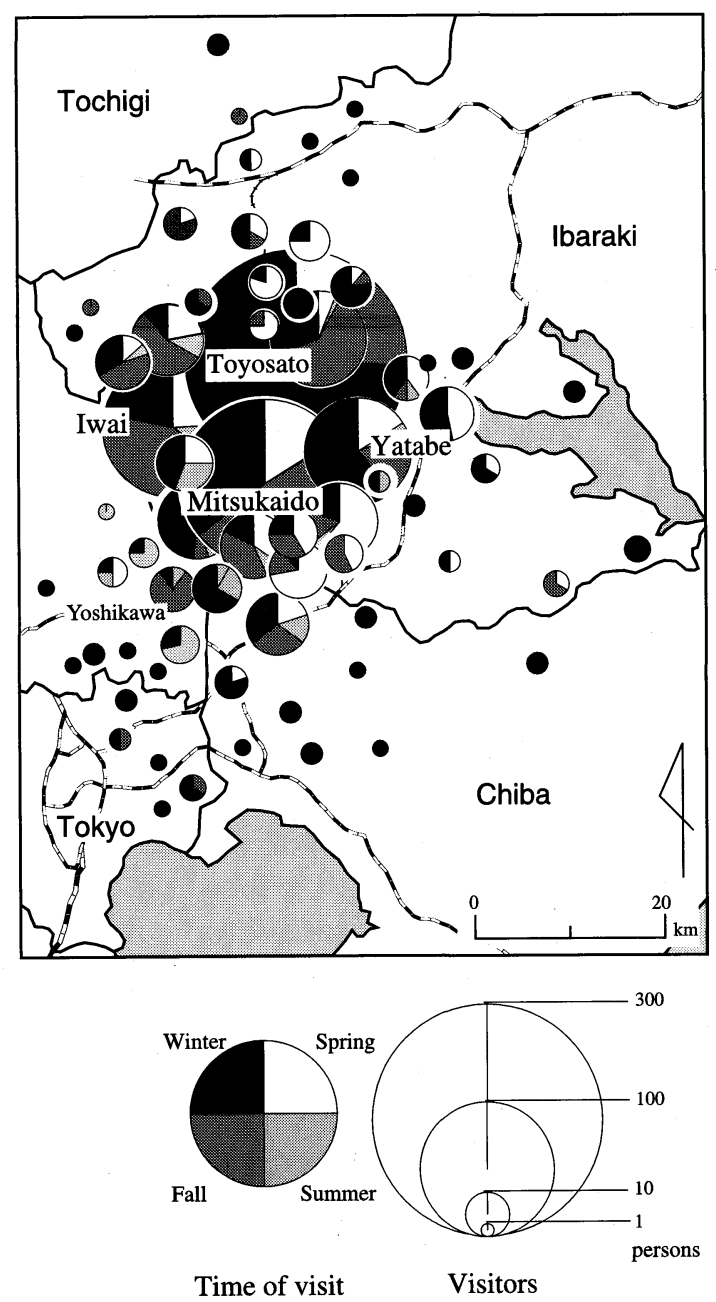

Figure 2. Distribution of prayers to the Kanamura Shrine, 1995.

There is a believer in Kanagawa, Aichi and Nagano. They all visit in winter. Data source: The Kanamura Shrine office. kuba City, where the shrine is located, has the most believers of 273, followed by Mitsukaido City with 155 believers, Iwai City with 107 believers, and the Yatabe district in Tsukuba City with 62 believers. Within the Toyosato district, 182 believers live in the ujiko area, occupying $67 \%$ of the total believers in the district. Thus, in contrast to the distribution of the religious associations, the distribution of individual believers shows gradual decrease in density in inverse proportion to the distance from the shrine. While the core areas of the Kanamura religious associations lie in the zone between 10 and 30 kilometers from the shrine, most individual believers dwell in the inner zone. Therefore, whereas there are 31 believers in Noda City which has 20 religious associations, there are only 12 believers in Yawahara Village which has as many religious associations as 21 . The spread of individual believers, however, is wider than that of the religious associations.

Concerning the time of visit, winter (from December to February) sees the most visitors, 495 (48\%). This is due to the Japanese custom of visiting shrines at the New Year (hatsumode), and 348 people visited the Kanamura Shrine on just New Years Day in 1996. Although this tendency that more people visit the shrine in winter than in any other season can be seen almost everywhere, it is more obvious in the inner zone including the Toyosato and Yatabe districts in Tsukuba City, and also in the outer zone of Kanagawa, Tokyo, and Tochigi.

Fall (from September to November) follows winter in the number of believers visiting the Kanamura Shrine and has 279 visitors (27\%). Spring (from March to May) comes next with 196 visitors (19\%) and summer (from June to August) sees the fewest visitors of 61 (5.8\%). Of the fall visitors, 74 come from Mitsukaido City, 47 from Iwai City, 38 from the Toyosato district in Tsukuba City, and 30 from Ishige Town. Of the spring visitors, 26 come from Iwai City, 25 from Mitsukaido City, 22 from the Toyosato district of Tsukuba City, and 19 from Ina Town. Many of these spring and fall visitors visit the shrine at the time of the festivals. Some representatives of the festival associations and group worship associations also make personal 
visits. The summer visitors pray for one's safety on the road, the safety in one's household, or protection against thunder, these later coming from relatively far places including Misato City, Sekiyado Town, and Sashima Town.

The author divided the religious sphere of the Kanamura Shrine into two regions based on the distribution of the Kanamura Shrine associations and individual believers (Matsui 1999).

The first area (inner area) is like an oval whose major axis is 50 kilometers and the minor is 20 kilometers. It lies from the western to the southern part of Ibaraki prefecture, including Yuki City, Yachiyo Town, Chiyokawa Village, Ishige Town, Mitsukaido City, Toyosato district in Tsukuba City, Yatabe district in Tsukuba City, Ina Town, Yawahara Town, Fujishiro Town and Toride City. There are two spatial characteristic in this area. One is to have a lot of group worship associations and amulet associations, the other is to account for more than 80 percent of believers.

The second area (outer area) lies in the outer zone of the first area, mainly extending to the southern. It includes the southwestern part of Iwai City and Sakai Town located in the western part of Ibaraki, Kawauchi Town, Azuma Town, Edosaki Town located in the southeast- ern part of Ibaraki, and around the southeastern part of Saitama, northwestern part of Chiba. There are also two spatial characteristic in this area. First, most festival associations and New Year's associations are organized in this area, second there are few individual believers dwelling in this area. Referring to believers, many of the vicarious visitors pray for their private wishes, and they are counted as believers. It is appropriate to consider this area as a main area of the distribution of both associations.

In this paper, I examine two study areas; the Toyosato district in Tsukuba City as an inner area and Yoshikawa City as an outer area. As we have seen, the Toyosato district, where the Kanamura Shrine is located, contains the ujiko area within it and has the most individual believers. In contrast, Yoshikawa City holds many festival associations that originated before the Meiji period, and constitutes a core area of the shrine in the outer zone.

\section{Regional Characteristics of the Kanamura Faith in the Toyosato District of Tsukuba City}

The Toyosato district lies at the center of western Ibaraki and occupies the western part

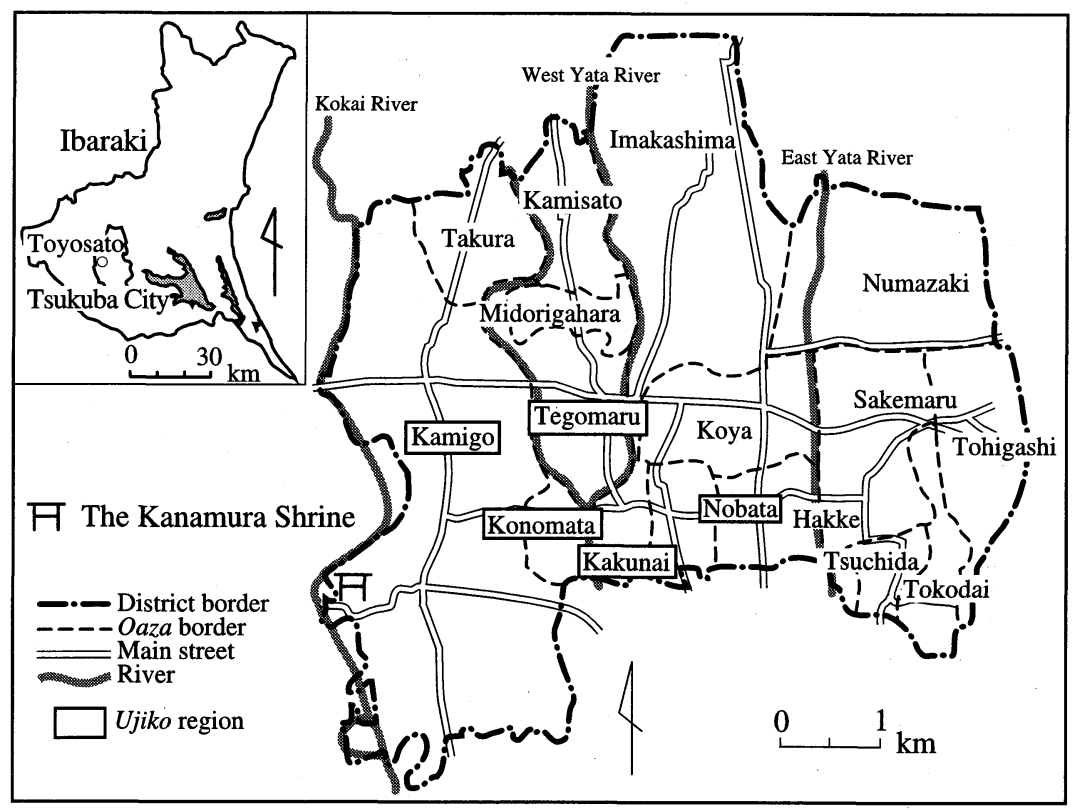

Figure 3. General view of Toyosato district, Tsukuba City, 1995. 
of Tsukuba City. (Figure 3). It is situated on the flat plateau about 25 or 30 meters above the sea level. Both the East and West Yata Rivers run through the district from north to south, and paddy fields are cultivated in their basins. The Kokai River also runs to the west and the lowlands in its basin are utilized as paddy fields. Volcanic ash covers the plateau, which is mainly used as forests or fields.

The Kamigo settlement containing the Kanamura Shrine constitutes the central settlement of the district and had 339 households and 1,662 people in 1724 (Takeuchi 1991). The reorganization of cities, towns, and villages in 1889 created Kamigo Village, Asahi Village and Yoshinuma Village. Kamigo Village consisted of four settlements, i.e., Kamigo, Konomata, Tegomaru and Nobata. In 1955, Kamigo Village and Asahi Village were combined together and became Toyosato Town. The next year, the town incorporated a part of Yoshinuma Village. In 1987, Toyosato Town, Yatabe Town, Oho Town and Sakura Village were integrated into Tsukuba City. The population of the Toyosato district in 1990 is 13,137 .

\section{Regional characteristics of the Kanamura faith in the 1930s}

Table 1 shows the prayers for rain made in 1931 and 1932 in the Toyosato district. With little rain in July and August, each settlement in the district asked for a prayer at the Kanamura Shrine under the name of its leader. The "Request for Rain-Making Prayers (Kiu goshinkan seikyusho)" kept at the shrine shows the names of the settlement, the village mayor, and the head of the settlement, fields damaged by the drought, the number of households, and the distance and direction of the settlement from the Kanamura Shrine. The representatives of the settlement ${ }^{5}$ put a seal on the request and brought it to the shrine to ask for a rainmaking prayer.

After the prayer, they were given holy water from the well at the north side of the shrine. They kept the holy water in a bamboo bottle and promptly brought it back to the settlement. ${ }^{6}$ In the settlement, the residents first put the water at a sacred place such as the tutelary shrine, offered sacred food and sake to it, and

Table 1. Record of prayer for rain in Toyosato district, 1931-2

\begin{tabular}{|c|c|c|c|c|c|c|}
\hline Year & Day of vịsit & Settlement & Hamlet & Offering & Visitors & Day of returning \\
\hline \multirow[t]{8}{*}{1931} & Aug. 7 & Kamigo & Kamishuku & 100 & - & Aug. 13 \\
\hline & Aug. 9 & Tohigashi & Tohigashi & 150 & 5 & Aug. 9 \\
\hline & Aug. 9 & Tegomaru & Tegomaru & 150 & 2 & Aug. 17 \\
\hline & Aug. 10 & Kamigo & Kanamura & 50 & 4 & Aug. 11 \\
\hline & Aug. 11 & Koya & Koya & 150 & 2 & Aug. 12 \\
\hline & Aug. 11 & Sakemaru & Sakemaru & 150 & 1 & Sep. 18 \\
\hline & Aug. 11 & Kamigo & Oshuku & 100 & 一 & Aug. 17 \\
\hline & Aug. 11 & Kamigo & Kakunai & 100 & 2 & Aug. 12 \\
\hline \multirow[t]{13}{*}{1932} & Jul. 16 & Kamigo & Osyuku, Kamisyuku, Yoko-machi & 500 & 2 & Jul. 22 \\
\hline & Jul. 21 & Kamigo & Hon-kanamura & 150 & 6 & Jul. 27 \\
\hline & Jul. 23 & Kamigo & Kakunai & 150 & 3 & Jul. 28 \\
\hline & Jul. 23 & Imakashima & Gotomaki & 150 & 8 & Jul. 28 \\
\hline & Jul. 24 & Koya & Koya & 150 & - & Jul. 28 \\
\hline & Jul. 24 & Kamigo & Oyama & 100 & - & Jul. 24 \\
\hline & Jul. 24 & Imakashima & Imakashima & 150 & 2 & Jul. 26 \\
\hline & Jul. 25 & Kamigo & Kamiyamori & 150 & 3 & Jul. 27 \\
\hline & Jul. 25 & Hakke & Hakke & 150 & 2 & Jul. 29 \\
\hline & Jul. 26 & Imakashima & Ikehata & 150 & 5 & Jul. 27 \\
\hline & Jul. 26 & Imakashima & Kaihata & 150 & 1 & Jul. 27 \\
\hline & Jul. 26 & Imakashima & Inarimae & 150 & 2 & Jul. 28 \\
\hline & Jul. 26 & Kamigo & Gonjo, Gonge, Nishihara, Daishuku & 900 & 1 & Jul. 27 \\
\hline
\end{tabular}

Unit: Yen, Persons. - - No data or not clear.

Data source: The Kanamura Shrine office. 
chanted Shinto prayers. Then, the holy water was mixed with local water and distributed to each household, so that people could sprinkle their fields with the holy water. It was customary to make a visit of gratitude back to the shrine within a week with "water in return" in the same bamboo bottle. ${ }^{7}$ There were some taboos concerning this rain-making prayer, such as those prescribing the attendants to avoid women and children, prohibiting them from chatting and eating eggs and bamboo shoots. These taboos indicate the communal character of the rain-making prayer.

Within the Toyosato district, Imakashima was especially prone to water shortage, as it was on a plateau. Before the Second World War, each hamlet at Imakashima made a rainmaking prayer in dry weather. People put a big tub filled with water in the yard of their assembly hall and mixed holy water from the Kanamura Shrine into it. All of the young men in the hamlet gathered around the tub, wearing only a loincloth, and splashed water on each other, shouting a charm. It was said to be done in a vociferous way with loud drum beat. In the area north of Imakashima, ${ }^{8}$ young men wearing only a loincloth gathered at the open space in front of a kannon temple and filled a tub located at the center with water. To obtain holy water, young representatives went to the Tsukuba Shrine, while middle-aged and elderly representatives went to the Kanamura Shrine and the tutelary shrine respectively. After pouring the holy water into the tub, they chanted a charm to the beat of a drum and splashed water on each other. This ritual continued until it rained. As these examples show, before the Second World War, when there were not enough wells and people used rainwater for farming, the community depended upon the Kanamura Shrine for rain-making prayers. ${ }^{9}$

Figure 4 shows the distribution of the indi-

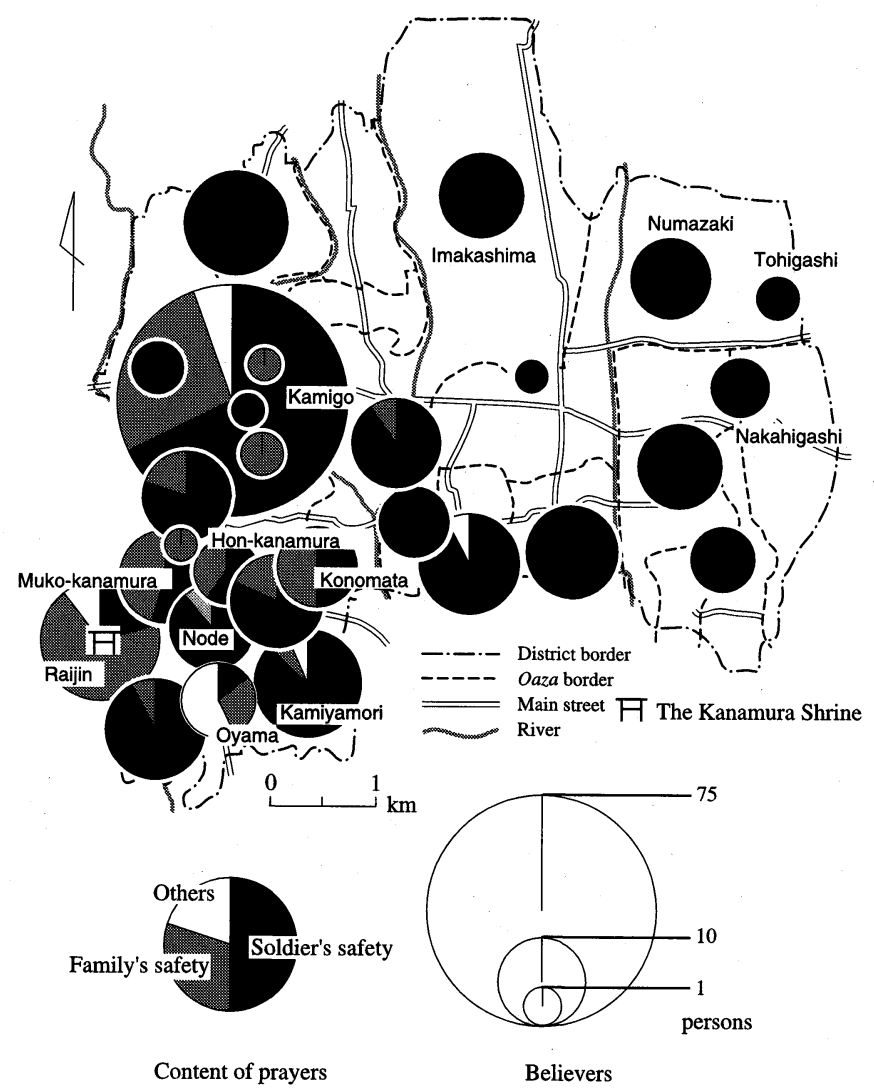

Figure 4. Distribution of believers in Toyosato district, 1931. Data source: The Kanamura Shrine office. 
vidual believers in the Toyosato district who asked for a prayer between April 1931 and March $1932 .{ }^{10}$ There is a total of 287 people who asked for a prayer, and many of them lived in Kamigo. Prayers for the safety of soldiers amount to 218 cases, $75 \%$ of the total, followed by 58 cases $(20.2 \%)$ of prayers for the safety of one's family. The Manchurian Incident occurred in 1931 and, therefore, the majority of the prayers at the Kanamura Shrine were made by soldiers' families for their safety. ${ }^{11}$ Back then, it was common to make prayers for victory in war or for the safety of soldiers at Shinto shrines. Prayers for the safety of soldiers, in particular, were usually made at tutelary shrines and other local shrines, and the fact that people in the Toyosato district asked the
Kanamura Shrine to make such prayers indicates the tutelary status of the shrine (I term it local shrine) for them.

As we have seen, as a community, people in the Toyosato district asked the Kanamura Shrine to perform rain-making prayers, while as an individual, they requested the shrine to protect their soldiers. This shows that the Kanamura Shrine was worshipped for its ability to make rainfall on the one hand, and, on the other, it served as a local shrine in the district.

\section{Regional characteristics of the Kanamura faith in 1995}

Table 2 shows the state of the Kanamura religious associations in the Toyosato district in 1995. There are 12 associations including 6

Table 2. Religious characteristics of Kanamura associations in Toyosato district, Tsukuba City, 1995

\begin{tabular}{|c|c|c|c|c|c|c|c|}
\hline Categories & No. & Name of place & $\begin{array}{c}\text { Year of } \\
\text { foundation }\end{array}$ & Range & $\begin{array}{l}\text { Number of } \\
\text { households }\end{array}$ & $\begin{array}{c}\text { Number of } \\
\text { managers }\end{array}$ & Attribute \\
\hline \multirow{6}{*}{$\begin{array}{c}\text { Festival } \\
\text { association }\end{array}$} & 1 & Koya & $1940 \mathrm{~s}$ & Settlement & 62 & 3 & - \\
\hline & 2 & Tohigashi & $1940 \mathrm{~s}$ & Settlement & 50 & 1 inherited & - \\
\hline & 3 & Nakahigashi & - & Settlement & 43 & 3 & $\mathrm{RU}^{\mathrm{a}}$ \\
\hline & 4 & Kamisato & 1991 & Settlement & 106 & 6 & RU \\
\hline & 5 & Imakashima-kaihata & $1940 \mathrm{~s}$ & Hamlet & 85 & 1 & $\mathrm{RU}$ \\
\hline & 6 & Imakashima-tsubakimoto & $1940 \mathrm{~s}$ & Hamlet & 39 & 1 & $\mathrm{HD}^{\mathrm{b}}$ \\
\hline \multirow{5}{*}{$\begin{array}{c}\text { Amulet } \\
\text { association }\end{array}$} & 7 & Imakashima-kamishuku & $1940 \mathrm{~s}$ & Hamlet & 48 & 2 & RU \\
\hline & 8 & Kakunai & - & Hamlet & 39 & 1 & RU \\
\hline & 9 & Konomata & - & Settlement & 38 & 3 inherited & - \\
\hline & 10 & Yoko-machi & - & Hamlet & 46 & 1 & $\mathrm{HD}$ \\
\hline & 11 & Oyama & - & Hamlet & 40 & 7 & $\mathrm{HD}$ \\
\hline
\end{tabular}

\begin{tabular}{|c|c|c|c|c|c|c|c|c|}
\hline Categories & No. & Name of place & Term & $\begin{array}{c}\text { Way of } \\
\text { visit }\end{array}$ & $\begin{array}{l}\text { Number } \\
\text { of visitors }\end{array}$ & Visitors & Rite & Amulets \\
\hline \multirow{6}{*}{$\begin{array}{c}\text { Festival } \\
\text { association }\end{array}$} & 1 & Koya & 1 year & $\mathrm{FV}^{\mathrm{c}}$ & 3 & Fixed to manager & No & $\mathrm{M}^{\mathrm{e}}$ \\
\hline & 2 & Tohigashi & No term & $\mathrm{FV}$ & 1 & Fixed to manager & No & $\mathrm{M}$ \\
\hline & 3 & Nakahigashi & 1 year & FV & 3 & Fixed to manager & No & M \\
\hline & 4 & Kamisato & 6 years & FV & 6 & Fixed to manager & No & M \\
\hline & 5 & Imakashima-kaihata & 2 years & $\mathrm{FV}$ & 1 & Fixed to manager & No & M \\
\hline & 6 & Imakashima-tsubakimoto & 2 years & FV & 1 & Fixed to manager & No & M \\
\hline \multirow{5}{*}{$\begin{array}{c}\text { Amulet } \\
\text { association }\end{array}$} & 7 & Imakashima-kamishuku & 1 year & $N^{d}$ & 2 & Fixed to manager & No & $L^{f}$ \\
\hline & 8 & Kakunai & 1 year & NV & 1 & Fixed to manager & No & $\mathrm{L}$ \\
\hline & 9 & Konomata & No term & $\mathrm{NV} \& \mathrm{FV}$ & 1 or 2 & Fixed to manager & No & $M \& L$ \\
\hline & 10 & Yoko-machi & 2 years & NV & 1 & Fixed to manager & No & $\mathrm{L}$ \\
\hline & 11 & Oyama & & NV & 7 & Fixed to manager & No & M \\
\hline
\end{tabular}

\footnotetext{
a RU: Representative of ujiko.

${ }^{\mathrm{d}} \mathrm{NV}$ : Vicarious visit in Jan.

${ }^{b}$ HD: Head of district.

${ }^{\mathrm{e}} \mathrm{M}$ : Amulets of middle sized for dedicating to a household altar.

${ }^{c} \mathrm{FV}$ : Vicarious visit in fall.

${ }^{\mathrm{f}} \mathrm{L}$ : Amulets of large sized for tsujifuda.

There is another association in Toyosato. - No data or not clear.

Data source: The author's field survey.
} 
group worship associations and 6 amulet associations. ${ }^{12}$ These Kanamura associations in the Toyosato district are based on territorial relationships and all of the households except for new comers associate themselves with them. To clarify the regional characteristics of the Kanamura faith in the Toyosato district, I will examine some of these associations in terms of the time of their foundation, their management system, and the mode of their activities in what follows.

As for the founding time, most group worship associations were organized in the 1940s with the exception of Kamisato which was organized in 1991. In the case of amulet associations, most of them are unclear about when they were founded. The names of Kamigo and Oyama appear in the list of visitors in 1931 and it is surmised that many other amulet associations were also organized by the time of the Second World War. Concerning the associations organized after 1940, there are three patterns in the way they came to be organized. First, the shrine encouraged it. Those living in Raijin made their living through business in front of the Kanamura Shrine. These people fostered the organization of the Kanamura religious associations in order to increase the number of visitors to the shrine. ${ }^{13}$ Instead of the priests, these Raijin people contacted each association and offered $30 \%$ of the money collected as a membership fee to the shrine. Early in the Showa era, these group worship associations were called kangiku (chrysanthemum) group worship associations because they acquired a new recreational function of letting people enjoy chrysanthemums in the precinct of the shrine. During the war, they changed their name to Kanamura raijin sensho kigan (to make prayers for victory in war) group worship associations. Few documents about the group worship associations have survived today but it is said in Kaihata of Imakashima and in Koya that the Raijin people including the Kanamura priests helped organize their group worship associations.

The second pattern concerns the organization of the group worship associations in Kamisato. The main priest of the Kashima Shrine, the tutelary shrine in Kamisato, died in 1990 and the chief priest of the Kanamura Shrine took over the ceremonies at the Kashima Shrine. In 1991, the managers of the ujiko organization of Kamisato founded a group worship association in gratitude. The case of the amulet association in Kamishuku of Imakashima constitutes yet another pattern. Before the Second World War, Kamishuku had a religious association called the Osugi association, the purpose of which was to support vicarious visits to the Osugi Shrine in Sakuragawa Village, Ibaraki. At the time, Kamishuku and four other settlements in northern Imakashima formed a unity in terms of religious activities and the vicarious visits to the Osugi Shrine was a part of those activities. After an interval during the war, people in Kamishuku started to dispatch their own representatives to the Kanamura Shrine. There are some other examples of the Kanamura associations being founded after the Second World War in places like Kakunai and Kamigo where people had felt affinity with the shrine through the rain-making prayers since before the war.

As for the management systems of the Kanamura religious associations, it is characteristic of the Toyosato district that, in 9 settlements out of 11 , the status of manager is not hereditary and people take turns to be the manager. ${ }^{14}$ In the eight settlements other than Koya, Tohigashi, and Konomata, the representative of the ujiko organization of the tutelary shrine or the head of the settlement becomes the manager. This means that the local religious organization and the local administrative organization are affiliated with the Kanamura association and the head of those organizations becomes in charge of the Kanamura association. Because the Kanamura association is thus dependent upon other religious or administrative organizations, its manager changes after a year or two as his position in this other organization comes to an end.

Let us now examine the activities of the Kanamura associations. The group worship associations send their representatives to the shrine in fall, while the amulet associations send theirs in January. Although the shrine determines when to visit for the group worship associations, it could still be said that the frequency of 
vicarious visits in the Toyosato district is lower than in Yoshikawa district which will be discussed later in this paper. The manager becomes the representative in each settlement: It is characteristic of the Toyosato district that members of the association do not take turns to be the representative. ${ }^{15}$ None of the Kanamura associations in the Toyosato district holds religious rituals like drawing of lots to decide the representative or sharing of a religious meal after the vicarious visit. This indicates that the Kanamura associations do not function as an autonomous religious organization.

From what we have seen, it is clear that there are two types of the Kanamura associations in the Toyosato district: the amulet associations originated as religious groups with the purpose of making prayers for rain, and the group worship associations organized through the efforts of the shrine and the Raijin people after the 1930s. The Kanamura associations are affiliated with the local religious and administrative organizations and the head of these organizations become in charge of the Kanamura associations. Accordingly, the Kanamura associations cannot be considered as independent religious bodies with autonomous functions. This is apparent in the fact that these associations do not perform religious rituals and that the frequency of vicarious visits to the shrine is low.

Figure 5 shows the distribution of the 261 individual believers whose addresses are clear and who visited the shrine between April 1995 and March 1996. There are 183 believers, which amounts to $70.1 \%$ of the total, who live in Kamigo, the ujiko area of the shrine. They concentrate especially in the areas adjacent to

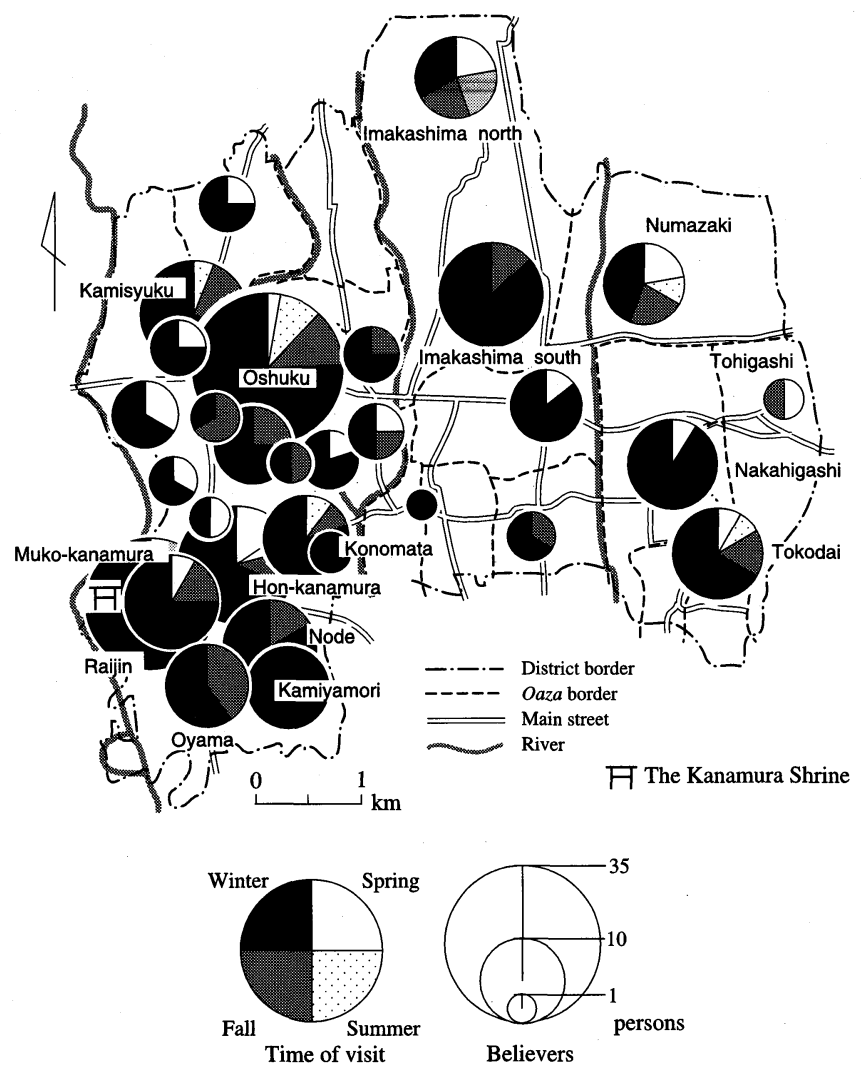

Figure 5. Distribution of believers in Toyosato district, 1995.

Sakemaru and Numazaki are summed up by oaza, because of limited data. Imakashima-south: Kamishuku, Gotomaki, Shimosyuku, Ikehata and Teramachi. Imakashima-north: Imashinden, Kaihata, Tsubakimoto and Inarimae. Data source: The Kanamura Shrine office. 
the shrine such as Raijin, Hon-kanamura, and Muko-kanamura, and also in the central areas of Kamigo such as Oshuku and Kamishuku. Over three quarters of the believers (75.6\%) made their visit in January. This makes a stark contrast to the data from 1931, when more than $75 \%$ of the visitors asked for prayers for the safety of soldiers and therefore many of them visited the shrine in months other than January. In 1995, most individual believers visited

Table 3. Proportion of believers per all households by community in Toyosato, Tsukuba City, 1995

\begin{tabular}{|c|c|c|c|c|}
\hline $\begin{array}{c}\text { Name of } \\
\text { District }\end{array}$ & $\begin{array}{c}\text { Name of } \\
\text { Place }\end{array}$ & $\begin{array}{c}\text { Number } \\
\text { of all }\end{array}$ & $\begin{array}{c}\text { Number } \\
\text { of } \\
\text { believers }\end{array}$ & $\begin{array}{c}\text { Ratio } \\
(\%)\end{array}$ \\
\hline Kamigo & Raijin & 31 & 21 & 67.7 \\
\hline Kamigo & Node & 23 & 12 & 52.2 \\
\hline Kamigo & Muko-kanamura & 33 & 12 & 36.4 \\
\hline Kamigo & Kamisyuku & 48 & 13 & 27.1 \\
\hline Kamigo & Hon-kanamura & 73 & 18 & 24.7 \\
\hline Kamigo & Oyama & 41 & 9 & 22.0 \\
\hline Kamigo & Shinsyuku & 19 & 4 & 21.1 \\
\hline Kamigo & Gonge & 40 & 8 & 20.0 \\
\hline Kamigo & Dokaku & 73 & 10 & 13.7 \\
\hline Kamigo & Osyuku & 213 & 29 & 13.6 \\
\hline Kamigo & Yoko-machi & 46 & 5 & 10.9 \\
\hline Kamigo & Kamigo & & 4 & 9.3 \\
\hline Kamigo & Gonjo & 38 & 3 & 7.9 \\
\hline Kamigo & Nishihara & 31 & 2 & 6.5 \\
\hline Sakemaru & Sakemaru & 141 & 9 & 6.4 \\
\hline Kamigo & Kamiyamori & 86 & 5 & 5.8 \\
\hline Kamigo & Asahi-machi & 35 & 2 & 5.7 \\
\hline Konomata & Konomata & 38 & 2 & 5.3 \\
\hline Koya & Koya & 117 & 5 & 4.3 \\
\hline Imakashima & Imakashima-S ${ }^{a}$ & 321 & 13 & 4.0 \\
\hline Numazaki & Numazaki & 209 & 8 & 3.8 \\
\hline Yoshinuma & Takura & 108 & 4 & 3.7 \\
\hline Tokodai & Tokodai & 277 & 10 & 3.6 \\
\hline Hakke & Hakke & 89 & 3 & 3.4 \\
\hline Kamigo & Daisyuku & 60 & 2 & 3.3 \\
\hline Tohigashi & Tohigashi & 71 & 2 & 2.8 \\
\hline Imakashima & Imakashima- $\mathrm{N}^{\mathrm{b}}$ & 263 & 7 & 2.7 \\
\hline Tegomaru & Tegomaru & 158 & 4 & 2.5 \\
\hline Kamigo & Kakunai & 40 & 1 & 2.5 \\
\hline Nobata & Nobata & 40 & 0 & 0.0 \\
\hline Kamigo & Shide & 20 & 0 & 0.0 \\
\hline
\end{tabular}

Unit: Household.

a Imakashima-S: Kamishuku, Gotomaki, Shimosyuku, Ikehata and Teramachi.

b Imakashima-N: Imashinden, Kaihata, Tsubakimoto and Inarimae.

Data source: The Kanamura Shrine office. the shrine at New Year and asked for prayers for the safety of their family.

Table 3 shows the proportion of individual believers of all the households in each community. Out of 3,135 households (1996) in the Toyosato district, there are 227 households of individual believers, which amounts to $7.2 \%$. The ratio changes radically between the ujiko area (Kamigo, Konomata, Tegomaru, Nobata) and other areas. In the ujiko area, 166 households out of 1,229 are believers (ratio 13.5\%). In other areas, there are only 61 believers out of 1,906 households (ratio 3.2\%). Even within the ujiko area, the ratio varies from settlement to settlement. In Kamigo, where the Kanamura Shrine is located, the ratio goes up to $16.1 \%$, whereas in the other three settlements it is $2.5 \%$, with 2 believers in Konomata, 4 in Tegomaru, and none in Nobata. These three settlements constituted a different village up to 1889 and the residents there feel that the Kanamura Shrine is the shrine of Kamigo. As for settlements, Raijin has the highest ratio of $67.7 \%$, followed by neighboring settlements including Node, Muko-kanamura and Hon-kanamura.

\section{Relations between the Kanamura priest and the local communities}

This section will examine the relationship between the priests of the Kanamura Shrine and local tutelary shrines in the Toyosato district. Figure 6 shows the distribution of the Kanamura religious associations and the "additional shrines" of the Kanamura priests in 1977 and $1995 .{ }^{16}$ In 1977, 14 tutelary shrines in the district were under the charge of the Kanamura priests as their additional shrines. At these additional shrines, the Kanamura priests perform ceremonies unless there is a temporary priest or a priest living in the settlement. In all of the settlements that had the additional shrines except for Tegomaru and Nobata, there existed Kanamura religious associations. ${ }^{17} \mathrm{Al}-$ though the number of the Kanamura associations is smaller in 1995, a new association has been founded in Kamisato, whose tutelary shrine has recently became an additional shrine of the Kanamura priests.

What does it mean that the Kanamura priests take charge of local tutelary shrines? Figure 7 

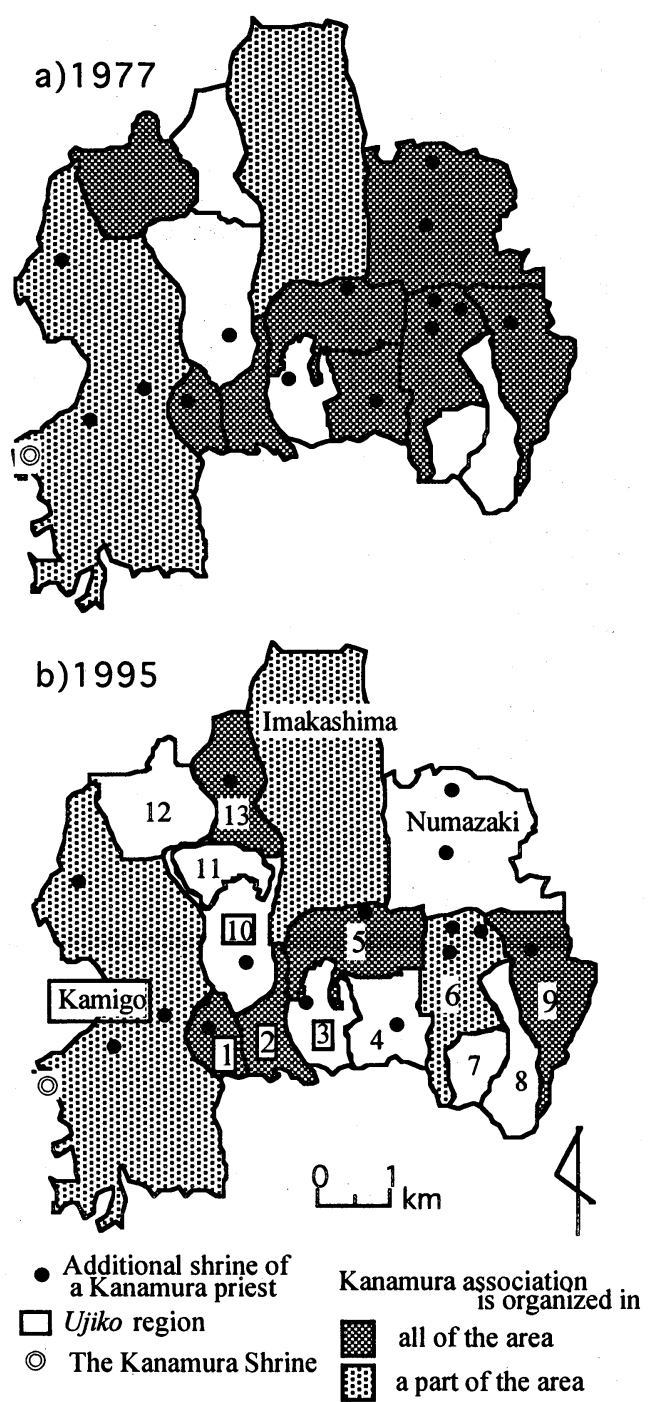

1 Konomata

$\begin{array}{ll}2 \text { Kakunai } & 8 \text { Tokodai } \\ \text { 3 Nobata } & 9 \text { Tohigashi } \\ 4 \text { Hakke } & 10 \text { Tegomaru } \\ 5 \text { Koya } & 11 \text { Midorigahara } \\ 6 \text { Sakemaru } & 12 \text { Takura } \\ 7 \text { Tsuchida } & 13 \text { Kamisato }\end{array}$

Figure 6. Distribution of additional shrines and Kanamura associations in Toyosato district, Tsukuba City, 1977, 1995.

Data source: The author's field survey in December, 1996.

shows the settlements and households to which the Kanamura priests distribute the amulets of the Ise Shrine. ${ }^{18}$ The priests mail them to the

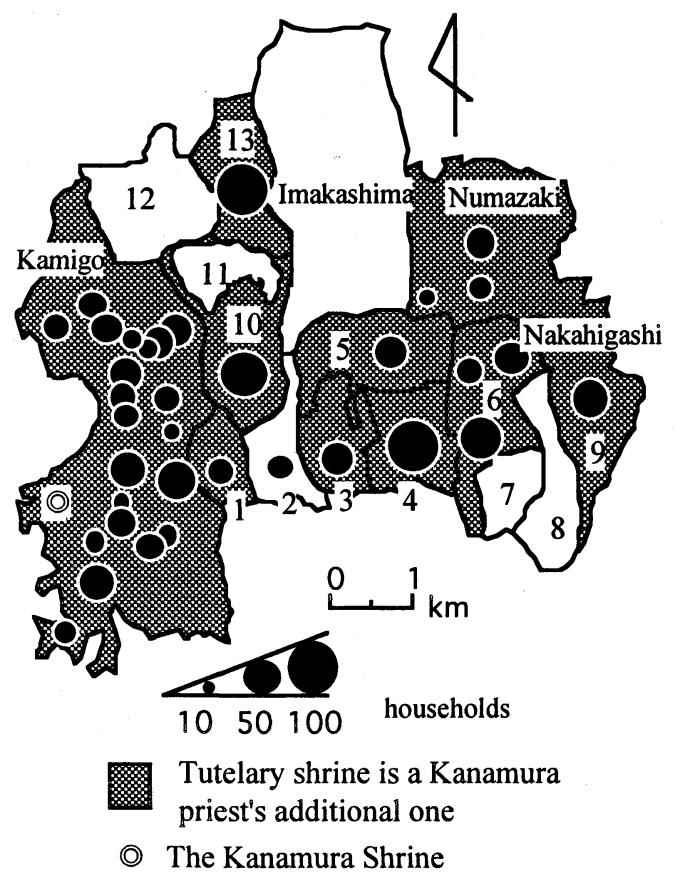

$\begin{array}{ll}1 \text { Konomata } & 8 \text { Tokodai } \\ 2 \text { Kakunai } & 9 \text { Tohigashi } \\ 3 \text { Nobata } & 10 \text { Tegomaru } \\ 4 \text { Hakke } & 11 \text { Midorigahara } \\ 5 \text { Koya } & 12 \text { Takura } \\ 6 \text { Sakemaru } & 13 \text { Kamisato } \\ 7 \text { Tsuchida } & \end{array}$

Figure 7. Distribution of communities which a Kanamura priest distributes amulets of Ise Shrine to people, 1995.

Data sources: The author's field survey in December, 1996.

managers of the Kanamura religious associations in Tohigashi and Konomata and to the representatives of the ujiko organizations of the tutelary shrines in other settlements. Figure 8 shows the system for distributing the amulets of the Ise Shrine. The Kanamura priests mail the amulets for the whole households in each settlement to the representative of the local ujiko organization (or the manager of the Kanamura religious association), who then sells them to those who want them and brings the money and unsold amulets to the Kanamura Shrine.

Figure 9 shows the settlements and households to which the Kanamura priests distribute the amulets of local tutelary shrines. ${ }^{19}$ People put the amulet on their household shrine in 


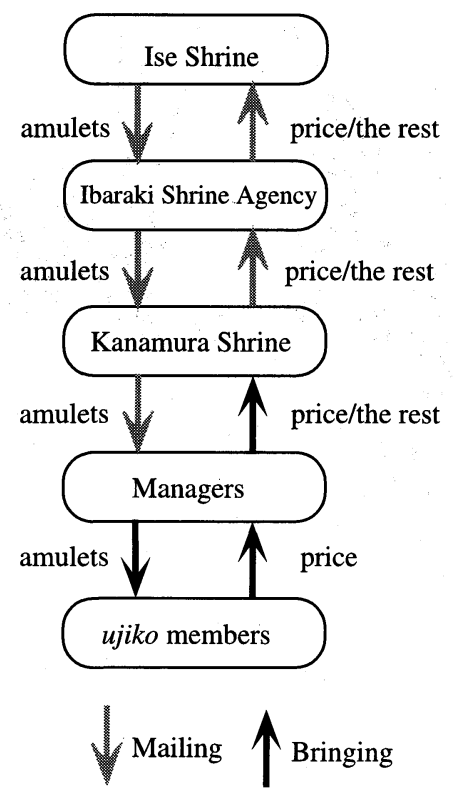

Figure 8. Distribution system of amulets of Ise Shrine to people in case of a Kanamura priest.

Arrow indicates flow of money and amulets. Data source: The author's hearing survey from a Kanamura priest.

January. We can see that the Kanamura priests play an important role in distributing amulets and performing ceremonies at tutelary shrines in the Toyosato district. The Kanamura Shrine thus has close relationship with the settlements in the Toyosato district through amulets and ceremonies in addition to people's visits to the shrine.

\section{Regional Characteristics of the Kanamura Faith in Yoshikawa City}

Yoshikawa City, located at southeastern Saitama, lies about 20 kilometers from central Tokyo and is seeing rapid urbanization recently (Figure 10). To the east, across the Edo River, there are Noda City and Nagareyama City of Chiba. To the west, across the Naka River, there are Matsubushi Town, Koshigaya City, and Soka City of Saitama. It is about 30 kilometers southwest of the Kanamura Shrine and constitutes the core area of the festival associations and New Year's associations together with Misato City and Yashio City of Saitama and Noda City and Nagareyama City of Chiba

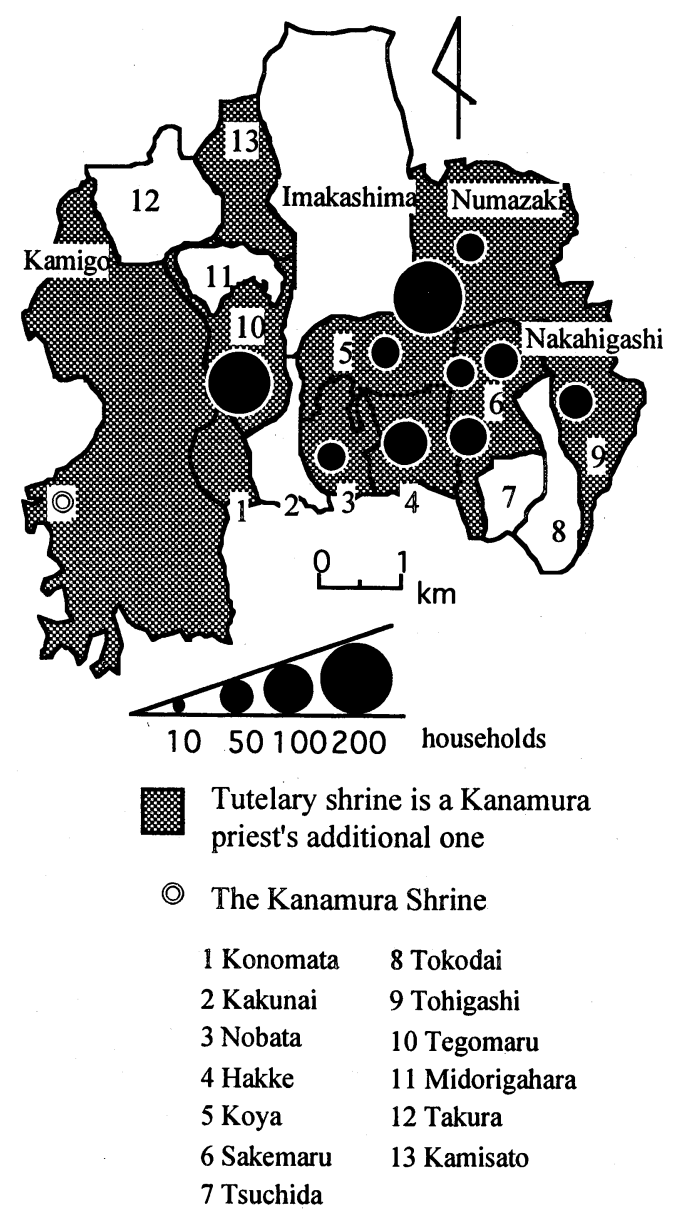

Figure 9. Distribution of communities which a Kanamura priest distributes amulets of a tutelary shrine to people, 1995. Data source: The author's field survey in December, 1996.

(See Figure 1). Flat marshland only 3 or 4 meters above sea level extends over most of Yoshikawa City, leaving it prone to floods. ${ }^{20}$ Within its area, the land is mostly used for farming, rice paddies in particular. The area developed as a distribution center of early rice crops using the Old Tone River as a means of transport during the mid-Tokugawa period (Takeuchi 1980). Except for the settlements on the natural bank of the Old Tone River, most of the settlements in the area did not start until the large-scale reclamation of rice paddies during the Tokugawa period. It is surmised that, in the 1820 s, the number of households within the limits of present-day Yoshikawa City was 1,646 


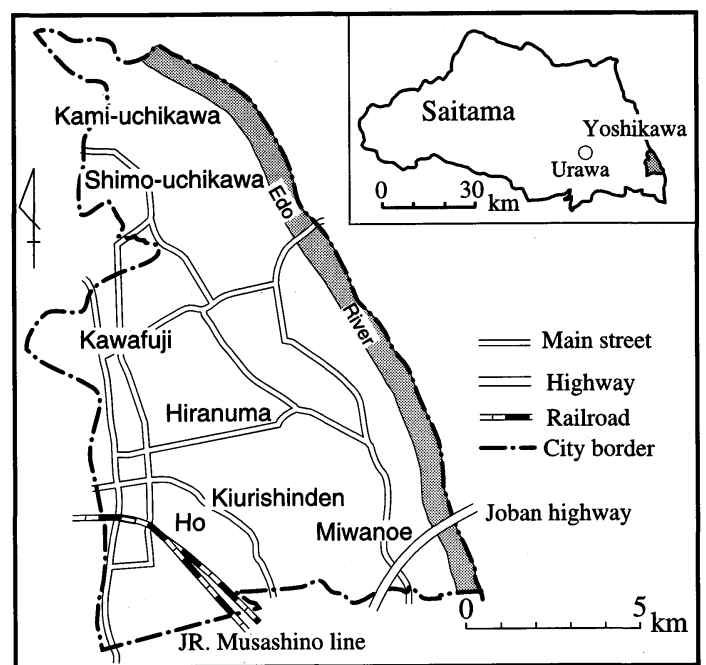

Figure 10. General view of Yoshikawa City, Saitama, 1996.

and the population was about 9,000.

In 1955, Yoshikawa Town integrated Asahi Village and Miwanoe Village of Kita-katsushika. In 1973, Yoshikawa Station opened on Musashino Line of the National Railways Corporation, which set off the still ongoing urbanization process. In the same year, people began to move into the housing complex north of the station and supermarkets started to pop up. The population increased 1.83 times between 1965 and 1975. In 1995, the town became Yoshikawa City and had the population of $52,668 .^{21}$

\section{Regional characteristics of the Kanamura faith before 1950}

Figure 11 shows the distribution of Kanamura associations in the Yoshikawa district in 1899 and 1949. In 1899, 17 settlements had Kanamura associations in the Yoshikawa district except for Asahi Village. ${ }^{22}$ The settlements in the western part on the natural bank of the Naka River were more likely to have Kanamura associations. In 1949, 19 settlements in the whole Yoshikawa district had Kanamura associations. ${ }^{23}$ We can see from Figure 11 that Kanamura associations were organized in at least 25 settlements by 1950 .

To clarify the activities of the Kanamura religious associations at the time, let us focus on the case of Kiurishinden. Kiurishinden is one of the newer settlements established through the large-scale reclamation of rice paddies in the late seventeenth century. There were 21 households there in the early eighteenth century and 26 in $1876 .{ }^{24}$ Their Kanamura religious association came into being by the time of the Meiji Restoration, though how it happened is not known. People worshipped the agricultural deity of the Kanamura Shrine and dispatched 4 representatives to the shrine at the time of the spring and fall festivals. There were 4 heredi-

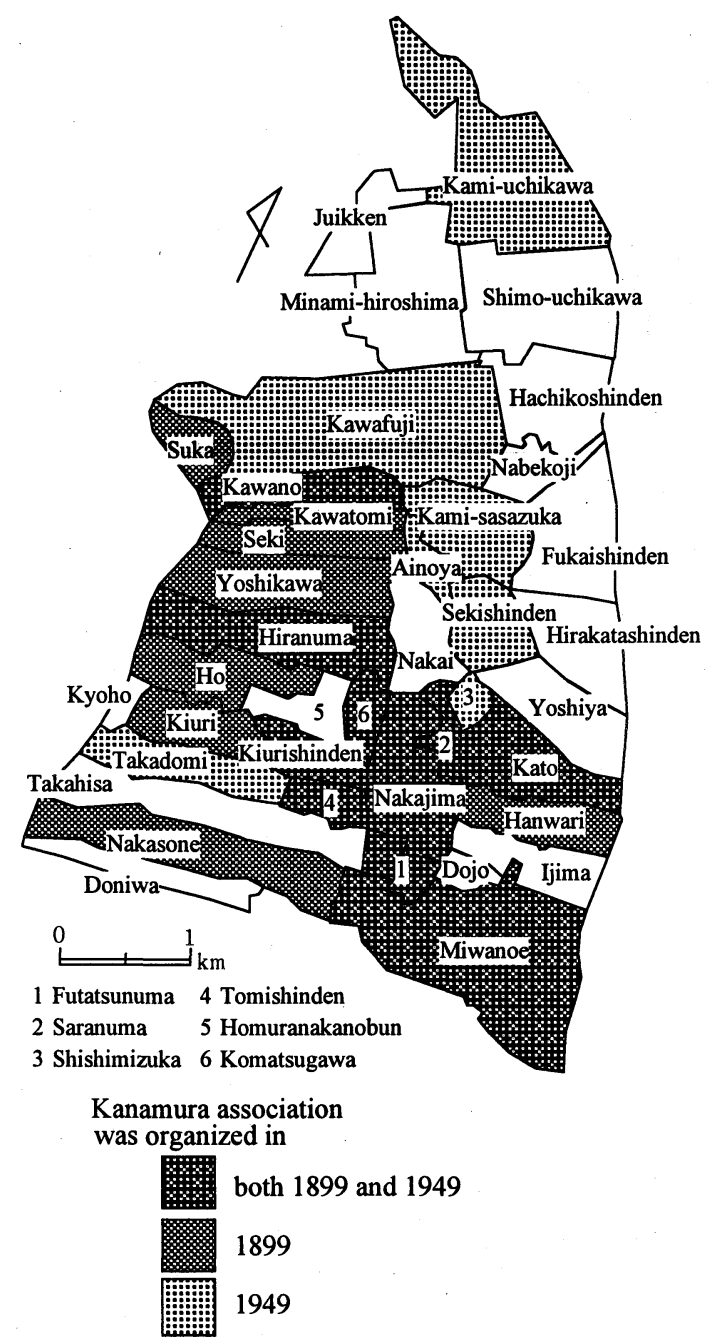

Figure 11. Distribution of Kanamura associations in Yoshikawa district, 1899, 1949.

Data source: Stele erected in the precincts of Kanamura, 1899 and the list of dedication for repairing the shrine roof, 1949. 
tary managers. Before the Second World War, it took two days to visit the shrine and the representatives stayed at Toriimae Town (literally, "Before-the-Gate Town") in Raijin. After they received the prayers, they were given amulets to put on the household shrine and amulets against insects for all the households in the settlement. Amulets against insects were to be put at the entrance to rice nurseries. The representatives also brought back holy water in the days of water shortage.

Right before the trip, people in Kiurishinden held a pre-visit meeting (musubi-ko), in which they drew lots to choose their representatives. The end of the trip was marked by a post-visit meeting (kanjo-ko). At this meeting, the representatives handed out the amulets they brought back from the Kanamura Shrine, reported the accounts, and shared a religious meal with the villagers afterwards. In 1995, they were still following this style of vicarious visit to the shrine, though the use of automobiles shortened the trip to one day. There were 18 households in the association.

Figure 12 shows the distribution of individual believers in the Yoshikawa district who visited the Kanamura Shrine between April 1931 and March 1932. In total, 21 believers asked for prayers. Of these, 12 people (57.1\%) made wishes concerning torigo, which is a system similar to godchild. If a baby is weak or mishaps have occurred to its parents after the birth, the parents often ask religious figures such as Buddhist monks or Shinto priests to be their child's torioya, or godparents (Hattori 1994). This system is one of the fictitious parent-child relations prevalent in Japan from ancient times. It has the purpose of ridding the child of ill fortune through the magical power of the religious figures who have become his/her torioya. The fact that people in the Yoshikawa district asked the Kanamura priests to be their children's torioya, therefore, indicates their faith in the magical efficacy of the shrine. The Kawafuji settlement had the most individual believers and their festival associations were organized during the Meiji period. The record of their vicarious visits show that the representatives also made their personal prayers when they visited the Kanamura

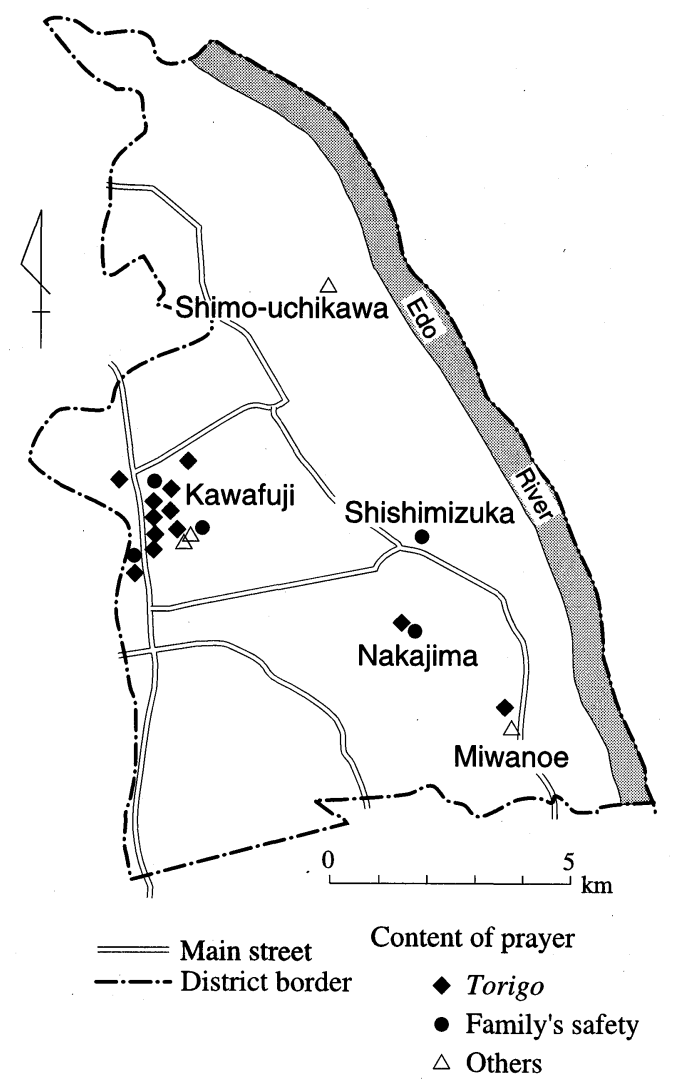

Figure 12. Distribution of believers in Yoshikawa district, 1931.

Data source: The Kanamura Shrine office.

Shrine.

While most of the individual believers visiting the shrine made prayers concerning torigo, none asked for the prayers for the safety of soldiers, the prayers most believers in the Toyosato district asked for. If these prayers signify people's belief in their tutelary deity, then we can surmise from this fact that the Kanamura Shrine was worshipped not as the tutelary deity but as a removed efficacious deity.

\section{Regional characteristics of the Kanamura faith in 1995}

Table 4 shows the mode of the Kanamura associations in the Yoshikawa district in 1995. There are 12 settlements that have the Kanamura religious associations: 3 settlements with both the festival associations and the New Year's associations, 7 with only the festival associations, 1 with only the New Year's associa- 
Table 4. Religious characteristics of Kanamura associations in Yoshikawa district, 1995

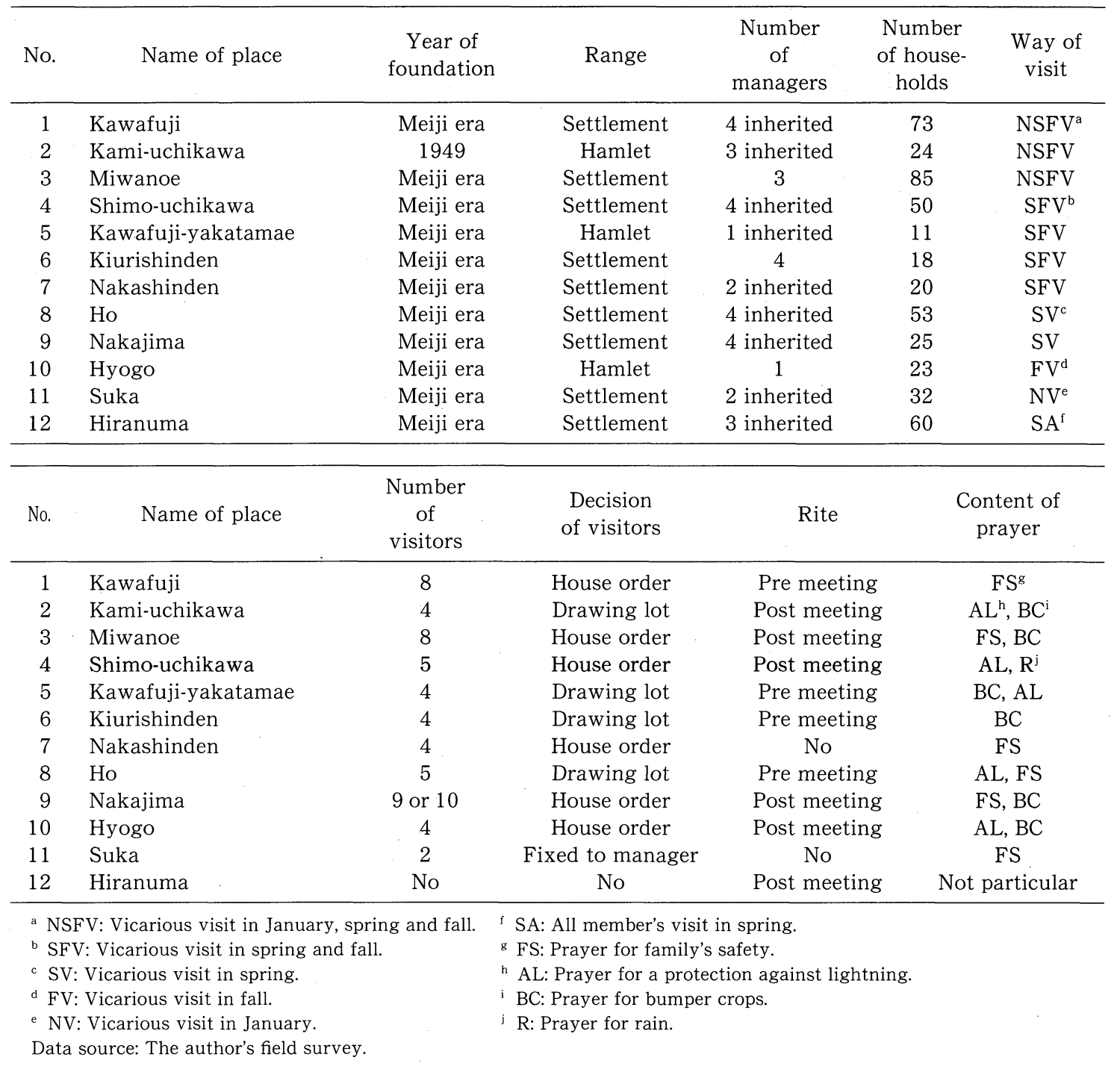

tion, and 1 with only the group worship association. Each of these associations is based on territorial relationships within a settlement. In what follows, I will compare the mode of these associations with that in the Toyosato district.

As for the time of foundation, 10 out of 12 settlements already had their associations during the Meiji period. ${ }^{25}$ None of these 10 settlements have retained stories about what caused the foundation of their association. Judging from the prayers people made toward the shrine such as for protection against thunder storm or for rain, however, it can be inferred that they organized these associations in the hope of having steady agricultural production through the efficacy of the Kanamura thunder deity. ${ }^{26}$ In the case of Kami-uchikawa, where the Kanamura association was founded after the Second World War, 2 (Nakamura and Shimo-shinhori) of the 6 hamlets in the area used to send their representatives to the Itakura Thunder Shrine in Gunma up to the war. After the war was over, people decided to dispatch their representatives to the Kanamura Shrine instead, because it was closer and had the same efficacy with the Itakura Shrine. This is an example of the Kanamura association organized for the purpose of making prayers for rain 
or protection against insects.

While about half of the Kanamura associations in the Toyosato district were organized after 1940, in the Yoshikawa district, most of the associations go back to the Meiji period or before. The neighboring cities of Nagareyama, Misato, and Yashio also have many Kanamura associations from the same period (Nagareyama City Museum 1991), which indicates that this area has been a core area of the Kanamura associations since the Meiji period.

In contrast to the Toyosato district, 9 settlements out of 12 have hereditary managers. The current managers in Nakajima, Ho, and Kawafuji-yakatamae are of the fourth generation, while those in Hiranuma, Suka, and Kawafuji are of the third generation. The status of manager is inherited from father to son, and to grandson. In most cases, a manager does not resign until his death and stays in the position however nominally in his old age, even though it is his family that do the practical jobs. That the term of the manager is this long makes a stark contrast with the Toyosato case. Even the number of managers has not changed. In the case of the Kanamura associations that have 3 or 4 managers, there have been no changes to their number since the foundation of the associations. Concerning the Kanamura association in Ho, for example, the documents dedicated to the Kanamura Shrine in 1894 shows 4 names as the managers, all of whom are the ancestors of the current managers. Even in settlements that do not have hereditary managers, there is no fixed term for managers and they keep the position until they die. Thus, in the Yoshikawa district, the Kanamura associations have fixed managers, which indicates that they are independent from other religious or administrative organizations.

Let us now examine other aspects of the $\mathrm{Ka}$ namura religious associations in the Yoshikawa district. They are basically the festival associations and dispatch their representatives twice a year, in spring and fall. From the three settlements where the New Year's association is organized in addition to the festival associations, that is, from Kawafuji, Kami-uchikawa, and Miwanoe, the representatives visit the shrine in January also. On the other hand, some settle- ments that have festival associations send their representatives only once a year, either in spring or fall. In Nakajima, for example, there are 9 to 10 representatives and each member used to become one quite frequently. Therefore, they have been sending their representatives only once a year in spring instead of twice since the 1970s. People in Hyogo and Miwanoe also used to dispatch their representatives twice a year. Although the frequency of visiting the Kanamura Shrine thus has declined recently, compared to the Toyosato district, it is still relatively high in the Yoshikawa district.

Members of the Kanamura associations take turns to be a representative in the Yoshikawa district. $^{27}$ After all of the members have become one, a new association starts the next year. There are basically two ways of choosing representatives: according to a fixed order or by lots. In the settlements that adopt lots, a previsit meeting is held before the vicarious visit and all the members gather together to choose their representatives. ${ }^{28}$ In Kawafuji-yakatamae, for example, there is a pre-visit meeting at the public hall a day before the vicarious visit. The representatives of the last visit prepare food and drink. The managers prepare 11 chopsticks, that is, one for each member, and mark four of them. Those who draw these marked chopsticks will visit the shrine the next day. On the wall of the public hall is hung a picture of the Kanamura Shrine and sake is offered to it. In Kiurishinden, they hold a pre-visit meeting half a month before the visit to reconfirm the members and choose their representatives. The managers make 19 twisted paper strings, one string more than the number of the members, and number them from 1 to 19. Each member draws one string, thus leaving one. Those who draw the numbers right before and after the number on the left string will visit the shrine. Thus, it is characteristic of the Yoshikawa district that the Kanamura associations adopt the rotation system in choosing their representatives and that all the members gather together to choose the representatives.

There are 6 settlements that hold a post-visit meeting after their representatives come back from the Kanamura Shrine. In Kami-uchikawa, the representatives visit the shrine in the morn- 


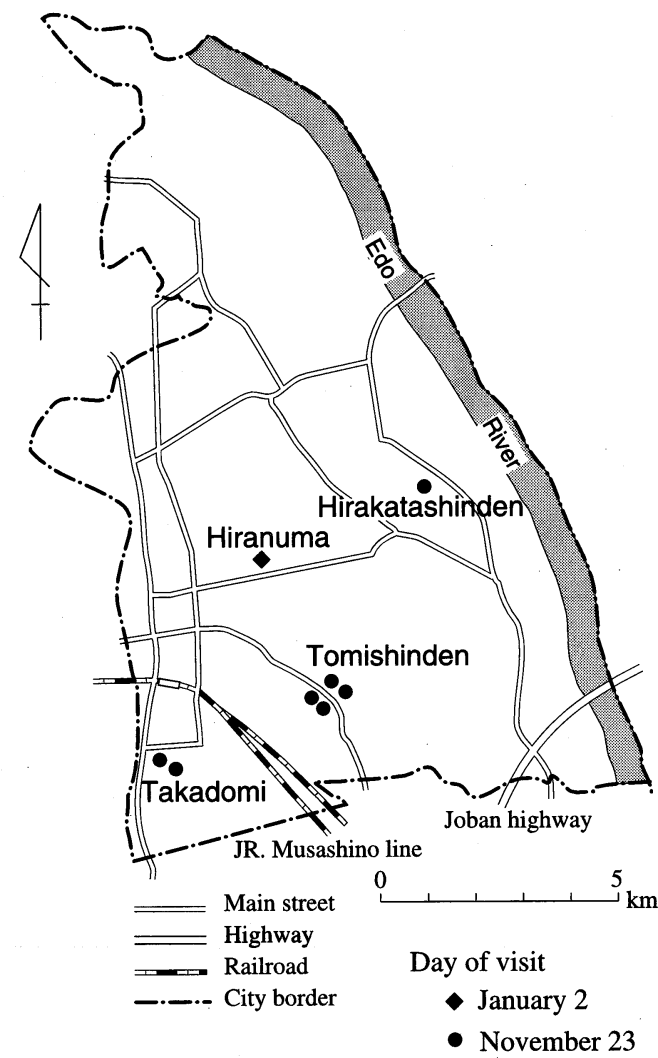

Figure 13. Distribution of believers in Yoshikawa district, 1995.

Data sources: The Kanamura Shrine office.

ing and then all the members come to the public hall to attend the post-visit meeting at three in the afternoon. At the post-visit meeting, the representatives distribute the amulets they have obtained at the shrine and the representatives for the next visit get chosen through drawing lots. In the Yoshikawa district, 8 out of 12 Kanamura associations hold a ritual and/ or a ritual feast before and after the vicarious visit, which signifies that these Kanamura associations have autonomous religious functions.

As for individual believers in the Yoshikawa district, there are 8 believers who asked for prayers at the Kanamura Shrine between April 1995 and March 1996 (Figure 13). Among them, 7 people made the visit at the fall festival on November 13, including 4 from Tomishinden and 2 from Takadomi. These two settlements used to have Kanamura religious associations until 1985 . It could be surmised that the believers from these settlements keep visiting the shrine at the time of the fall festival even after the Kanamura associations dissolved. Therefore, we can conclude that, for people in the Yoshikawa district, the Kanamura Shrine is a place to visit not as individual but through the religious associations.

\section{Conclusion}

In this paper, I have tried to clarify the regional differences in the mode of people's belief in the Kanamura Shrine between the outer and inner areas of its religious sphere. The Toyosato district, a typical district of the inner area, shows the characteristics summarized as follows.

This district contains both amulet associations, which originated in making prayers for rain sometime before the Second World War, and group worship associations, which did not start until the 1940s. These Kanamura religious associations do not function as autonomous religious groups and are dependent upon other religious or administrative organizations. Three facts prove this point. First, the position of the manager of these associations is basically non-hereditary and is often occupied by heads of other religious or administrative organizations such as the representatives of ujiko or the heads of settlements. Second, members of the Kanamura associations are the same as those of the ujiko organizations or other religious groups. Lastly, there are no meetings or ritual feasts in which all the members take part. The Kanamura religious associations in the Toyosato district, therefore, are hardly autonomous and are often incorporated within other religious or administrative organizations. Their sole objective is to distribute amulets of the Kanamura Shrine.

The majority of the individual believers of the Kanamura Shrine in the Toyosato district used to wish for the safety of soldiers before the war, and now wish for the safety of the family. These prayers do not have direct relation to the nature of the Kanamura deity. From this fact, we can see that the Kanamura deity is worshipped as the local tutelary deity, as well as a thunder and agricultural deity.

One of the factors causing people to regard 
the Kanamura Shrine as their tutelary deity is the close connection between the local communities and the shrine through the distribution of amulets. Many of the tutelary shrines in the Toyosato district are "additional shrines" of the Kanamura priests, who mediate in distributing the amulets of the tutelary shrines and of the Ise Shrine to people. The Kanamura priests also perform ceremonies at these tutelary shrines. Managers of the ujiko organizations have to stay in contact with the Kanamura priests over these matters. Because ujiko members take turns to be managers, all of them eventually become connected with the shrine. The relations thus established between the Kanamura Shrine and local residents have contributed to making it their tutelary shrine.

In the Yoshikawa district, a typical district of the outer area, there are few individual believers but many festival associations and New Year's associations going back to sometime before the Meiji period. The Kanamura associations in this district have their own managers and members, and function independently of the $u j i k o$, or other, religious organizations. This autonomy of the Kanamura religious associations is one of the regional characteristics of the outer area. It is also apparent in the existence of religious rituals such as pre or post-visit meeting in the activities of these associations. A second regional characteristic is that the Kanamura deity is not worshipped as people's tutelary deity but as an efficacious deity at a distance. For people in the Yoshikawa district, the Kanamura Shrine is not a place they visit individually to make personal prayers; it is a place they worship in their communities. When they do visit the shrine personally, they make prayers that are related to the nature of the Kanamura deity, that is, concerning torigo or for protection against thunder. When they worship the shrine in their communities, they expect its power to protect their fields from thunderstorms and bring about bumper crops. Unlike in the Toyosato distirct, there are no connections between the Kanamura priests and the settlements except through the vicarious visits to the shrine.

This paper fell short of considering the spatial significance of the religious sphere of the
Kanamura Shrine, that is, the causes and meanings of the regional differences we have seen above. I would like to explore this issue in the future.

\section{Acknowledgements}

I would like to thank Professor Nobuo Takahashi at the University of Tsukuba for his useful comments. I wish also to express my gratitude to Mr. Koji Tokoro at the Kanamura Betsurai Shrine and the managers of the Kanamura religious associations without whose help this paper would have been impossible. I am deeply grateful to Ms. Reiko Sono for her critical reading during the preparation of the English manuscript. This paper is a part of my dissertation submitted to the Department of Geoscience, University of Tsukuba.

(Received May 13, 1999)

(Accepted June 12, 1999)

\section{Notes}

1. The list of the Kanamura religious associations was revised in 1985, resulting in the abolishment of the older one. Figure 1 is based on the revised list.

2. Although the number of the settlements that have the Kanamura religious associations is 320 , the total number of the associations is 346 , because some settlements hold two types or more of these associations.

3. Individual believers are those who enter the main hall of the Kanamura Shrine and receive prayers by the priests.

4. This only includes the believers whose address is clear.

5. Usually, there are two of them.

6. Carrying holy water to their village, they took a rest as little as possible. A folklore said that if they took a rest somewhere, it would rain there and it had no rain in prayers' village. So they are said not to stop even at a red signal.

7. The water in return was called okaeshimizu.

8. The area includes Gotomaki, Kamishuku, Shimoshuku, Ikehata and Teramachi.

9. In the hamlet of Tsubakimoto in Imakashima, the last prayer for rain was made in 1941.

10. The Toyosato district includes Kamigo Village, Asahi Village and a part of Yoshinuma Village.

11. There were 187 soldiers from Kamigo Village and 251 from Asahi Village killed in the war from 1931 to 1945 (Toyosato-cho Shi Hensan Iinkai 1985). A monument to commemorate the loyal war dead was built in the precincts of the Kanamura Shrine.

12. In the ujiko area, each local community sends their representatives to the Kanamura Shrine 
to obtain amulets at the time of the fall festival. The shrine, however, regards these local communities as their ujiko and not as their religious associations. This paper follows the classification of the Kanamura Shrine.

13. The priests of the Kanamura Shrine made a contract with the Raijin people concerning solicitations to the group worship associations in October, 1928.

14. Tohigashi and Konomata adopt the hereditary system of managers. The current Tohigashi manager is of the second generation and the Konomata manager is of the third generation.

15. Because the manager changes every 2 or 3 years, however, the representative also changes frequently. In Tohigashi and Konomata, where the manager is hereditary, the manager still becomes the representative.

16. The law prescribes that every religious corporation must have a representative. If a priest belonging to a shrine becomes the representative of another, the latter is called an "additional shrine (kenmu sha)."

17. Both Tegomaru and Nobata are in the ujiko area and the representatives from these settlements visit the Kanamura Shrine at the time of the fall festival. Therefore, practically they also had the Kanamura religious associations.

18. The Kanamura Shrine receives the amulets from the Ise Shrine through mail via the Ibaraki Shinto Agency. The Kanamura priests then distribute them to their ujiko and also the ujiko of their additional shrines who want the amulets. The Kanamura priests collect the money for these amulets and give it to the Ise Shrine via the Ibaraki Shinto Agency.

19. If the tutelary shrine is the Kashima Shrine, amulets with its name on are distributed. In some settlements, the ujiko people print and distribute them themselves.

20. During the 270 years of the Tokugawa period, the area suffered from floods about 50 times. After the reconstruction of the river-banks of the Edo River in 1954, however, there has been no severe flood.

21. In this paper, Yoshikawa city area is called the Yoshikawa district.

22. For the distribution in 1899 , this paper uses the stele in the precinct of the Kanamura Shrine as the data. This stele was erected by the Kanamura associations in Miwanoe Village, Yoshikawa Village, and Waseda Village of Kita-katsushika (currently Misato City), Osagami Village and Masubayashi Village of Minamisaitama (currently Koshigaya City), and Nagareyama Town of Higashi-katsushika, Chiba. Since it does not include former Asahi Village in the Yoshikawa district, the distribution of the Kanamura associations there is unknown.
Asahi Village contains Kami-uchikawa, Shimouchikawa, Hachikoshinden, Nabekoji, Juikken, Minami-hiroshima, and Kawafuji.

23. The distribution in 1949 is based on the list of contributors to repairing the roof of the Kanamura Shrine.

24. In 1995, there were 180 households.

25. The existence of these associations during the Meiji period is affirmed through documents, steles, and lists of donators. They could have been founded during the Tokugawa period.

26. One of the Kanamura associations in neighboring Misato City started after a thunder damaged the area during the Taisho period (Misatoshi Shi Hensan Iinkai 1991). In Yashio City, there is a Kanamura association organized to make prayers for rain (Yashio-shi Shi Hensan Iinkai 1985).

27. In general, the managers of the New Year's associations receive amulets from the Kanamura Shrine through mail in January and distribute them to each member. In the case of the Yoshikawa district except for Kawafuji, however, the managers visit the shrine themselves and obtain amulets.

28. In Kami-uchikawa, they choose their representatives for the next time at the meeting after the visit.

\section{References}

Ariga, M. 1972. The faithful colony at the piedmont centering around the three mountains of Dewa. Regional Study 13: 37-42. (J)

Bjorklund, E. M. 1964. Ideology and culture exemplified in south-western Michigan. Annals of the Association of American Geographers 54: 227-241.

Clarke, C. J. 1985. Religion and regional culture: the changing pattern of religious affiliation in the Cajun region of southwest Louisiana. Journal for the Scientific Study of Religion 24: 384-395.

Hashimoto, N. 1987. Furumine jinja no shinkoken ni tsuite. Utsunomiya Chirigaku Nenpo 5: 29-39. (J)

Hattori, O. 1994. Torigo. In Nihon minzoku jiten (Encyclopedia of folklore), ed. Otsuka folklore association, 509-510. Tokyo: Kobundo. (J)

Hostetler, J. A. 1980. The old order Amish on the Great Plains: a study in cultural vulnerability. In Ethnicity on the Great Plains, ed. F. C. Luebke, 92108. Lincoln: University of Nebraska Press.

Ishitobi, K. 1976. Yakushima ni okeru sangaku shinkoken no kenkyu. Memoirs of Kagoshima Geographical Society 22: 130-138. (J)

Iwahana, M. 1981. Transfiguration of the mountain villages around Mt. Togakushi according to the development of tourism. Human geography 33: 458-472. (J)

Iwahana, M. 1983a. On the sphere of religion in Dewasanzan from the geographical point of view. Jour- 
nal of History 66: 681-726. (JE)

Iwahana, M. 1983b. The mountain villages founded by yamabushi around Mt. Dewa-sanzan. Geographical Review of Japan 56A: 535-552. (JE)

Iwahana, M. 1992. Togakushi shinko no chiikiteki tenkai. Japanese Mountain Religion 10: 31-40. (J)

Jordan, T. G. 1976. Forest folk, prairie folk; rural religious cultures in North Texas. Southwestern Historical Quarterly 80: 135-162.

Jordan, T. G. 1980. A religious geography of the hill country Germans of Texas. In Ethnicity on the Great Plains, ed. F. C. Luebke, 109-128. Lincoln: University of Nebraska Press.

Kaneko, N. 1995. A review of studies on the spatial structure of mountain religion in Japan. Humanities Review 45(3): 107-117. (J)

Kaneko, N. 1997. The spatial structure of mountain religion: the case of Mt. Iwaki. Human geography 49: 311-330. (JE)

Koyama, T. 1995. The beliefs of Mt. Iwaki as seen from the custom of the imitation mountain: in connection with fixing on the radius of the beliefs. Bulletin of the folklore society of Japan 203: $1-22$. (J)

Kushida, M. 1978. Kamigoshi shiryoko (Consideration to the history of Kamigo), Toyosato: Kamigoshi shiryo kankokai. (J)

Maki, M. 1980. Tsukubasan shinko no shinkoken. In Gendai syukyo 2 Tokusyu sangaku syukyo (Special number of mountain religion), ed. K. Sasaki, N. Miyata, and T. Yamaori, 141-160. Tokyo: Syunjusya. (J)

Matsui, K. 1998. Reexamination of recent studies on the geography of religion in Japan. Annual Report, Institute of Geoscience, University of Tsukuba 24: 7-12.

Matsui, K. 1999. Regional characters of Kanamura Betsurai Shrine faith. Tsukuba Studies in Human Geography 23: 39-58. (JE)

Meinig, D. W. 1965. The Mormon culture region: strategies and patterns in the geography of the American West, 1847-1964. Annals of the Association of American Geographers 55: 191-220.

Misato-shi Shi Hensan Iinkai ed. 1988. Misato shishi 9 Minzokuhen (History of Misato, folklore). Misato: Misato City. (J)

Miyamoto. K. 1974. Chiho reizan shinko no seiritsu to tenkai; Kabasan shinko wo tyushin to shite. In Nihon ni okeru seiji to syukyo (Politics and religion in Japan), ed. K. Kasahara, 285-311. Tokyo: Yoshikawa kobunkan. (J)

Miyata, N. 1961. Mountain belief and its fraternity. Journal of folklore 21: 5-14. (J)

Miyata, N. 1970. Iwakisan shinko; sono shinkoken wo megutte. In Tsugaru no minzoku (Folklore in Tsugaru, Aomori prefecture), ed. T. Wakamori, 277295. Tokyo: Yoshikawa kobunkan. (J)

Nagano, T. 1987. A historical geography of Mt. HikoShugendo. Tokyo: Meicho syuppan. (JE)

Nagareyama City Museum ed. 1991. Nagareyama shiritsu hakubutsukan tyosa kenkyu hokokusyo $8 \mathrm{Na}$ gareyama no ko (Religious associations in Nagareyama). Nagareyama: Nagareyama City Museum. $(\mathrm{J})$

Nishikai, K. 1979. Tsukubasan shinko no tenkai to daido-ko. In Sangakusyukyoshi kenkyu sosyo 8 Nikko san to Kanto no syugendo (Mt. Nikko and syugendo in Kanto Region), ed. N. Miyata and K. Miyamoto, 242-263. Tokyo: Meicyo syuppan. (J)

Shortridge, J. R. 1976. Patterns of religion in the United States. Geographical Review 66: 420-434.

Suzuki, A. (1992): Sagami Oyama shinko no seiritsu to tenkai (Formation and development of Oyama faith). In Minshu syukyo shi sosho 22 Oyama shinko (Oyama faith). ed. F. Tamamuro, 91-125. Tokyo: Yuzankaku. (J)

Takeuchi, R. ed. 1980. Kadokawa Nihon chimei jiten 11 Saitama ken (Encyclopedia of place name in Saitama prefecture). Tokyo: Kadokawa shoten. (J)

Takeuchi, R. ed. 1991. Kadokawa Nihon chimei jiten 8 Ibaraki ken (Encyclopedia of place name in Ibaraki prefecture). Tokyo: Kadokawa shoten. (J)

Toyosato-cho Shi Hensan Iinkai ed. 1985. Toyosato no rekishi (History of Toyosato). Tokyo: Toyosato Town. (J)

Trepanier, C. 1986. The Catholic church in French Louisiana: an ethnic institution?. Journal of Cultural Geography 7(1): 59-75.

Yashio-shi Shi Hensan linkai ed. 1979. Yashio shishi tyosa hokokusyo 1, Yashio no minzoku siryo (History of Yashio, folklore 1). Yashio: Yashio City. (J)

Zelinsky, W. 1961. An approach to the religious geography of the United States: Patterns of church membership in 1952. Annals of the Association of American Geographers 51: 139-193.

Zelinsky, W. 1973. The cultural geography of the United States. New York: Prentice-Hall. 